\title{
Egg white-mediated green synthesis of silver nanoparticles with excellent biocompatibility and enhanced radiation effects on cancer cells
}

This article was published in the following Dove Press journal:

International Journal of Nanomedicine

20 April 2012

Number of times this article has been viewed

\section{Renquan Lu' \\ Dapeng Yang ${ }^{2}$ \\ Daxiang Cui ${ }^{2}$ \\ Zhongyang Wang ${ }^{3}$ \\ Lin Guo'}

'Department of Clinical Laboratory, Fudan University Shanghai Cancer Center, Shanghai, ${ }^{2}$ Department of Bio-Nano-Science and Engineering, National Key Laboratory of Nano/ Micro Fabrication Technology, Key Laboratory for Thin Film and Microfabrication of Ministry of Education, Institute of Micro-Nano Science and Technology, Shanghai Jiao Tong University, Shanghai, ${ }^{3}$ College of Chemistry and Chemical Engineering, Yantai University, Shan Dong Province, People's Republic of China

Correspondence: Lin Guo Department of Clinical Laboratory, Fudan University Shanghai Cancer Center, 2nd Floor, Building 3, 270 DongAn Road, Xuhui district, Shanghai, People's Republic of China 200032

Tel +862I 64I755902204

Email jykca@sina.com

\begin{abstract}
A simple, cost-effective, and environmentally friendly approach to the aqueous-phase synthesis of silver $(\mathrm{Ag})$ nanoparticles was demonstrated using silver nitrate $\left(\mathrm{AgNO}_{3}\right)$ and freshly extracted egg white. The bio-conjugates were characterized by UV-visible spectroscopy, transmission electron microscopy, Fourier transform infrared spectrometry, and dynamic light scattering. These results indicated that biomolecule-coated Ag nanoparticles are predominantly spherical in shape with an average size of $20 \mathrm{~nm}$. The proteins of egg white, which have different functional groups, played important roles in reducing $\mathrm{Ag}^{+}$and maintaining product attributes such as stability and dispersity. In vitro cytotoxicity assays showed that these Ag-protein bio-conjugates showed good biocompatibility with mouse fibroblast cell lines 3T3. Furthermore, X-ray irradiation tests on 231 tumor cells suggested that the biocompatible Ag-protein bio-conjugates enhanced the efficacy of irradiation, and thus may be promising candidates for use during cancer radiation therapy.
\end{abstract} Keywords: green chemistry, biosynthesis, egg white, Ag nanoparticles, X-ray irradiation

\section{Introduction}

A key aim in X-ray irradiation-aided cancer therapy is to achieve a dose that avoids damage to healthy tissues and organs while maintaining an efficient therapy outcome. ${ }^{1}$ Nanobiotechnology may address this issue by improving the effectiveness and selectivity of X-ray irradiation therapy.

In recent years, bio-conjugated nanomaterials have shown significant potential for application in biological/biomedical fields through their use in luminescence tagging, labeling, drug delivery, and imaging. ${ }^{2-5}$ To fabricate an available bio-conjugate for such applications, it is important to select an appropriate synergism between the nanoparticle surface and biological molecules. Noble metal nanoparticles have attracted extensive attention, particularly in the biomedical field, due to their intriguing physical-chemical properties.

Many studies have examined the controlled synthesis of noble metal nanomaterials of various sizes and morphologies through the use of biomolecules as templates. ${ }^{6,7}$ Extracts from plants such as tea, aloe vera, apple, and pimiento have been successfully used to synthesize gold ( $\mathrm{Au}$ ) and silver (Ag) nanoparticles. ${ }^{8-12}$ Naturally occurring small molecules such as vitamins $\mathrm{B}_{2}, \mathrm{C}$, and $\mathrm{E}$ have been used to prepare $\mathrm{Au}$, platinum, and Ag nanomaterials. ${ }^{13-15}$ Proteins and peptides such as apoferritin, bovine serum albumin (BSA), lysozyme, and tryptophan-based peptides have also been used in the synthesis of Au and Ag nanoparticles. ${ }^{16-20}$

Compared with traditional chemical syntheses, biomolecule-assisted syntheses of noble metal nanomaterials have a number of advantages. ${ }^{7,21}$ Since biomolecule-assisted 
syntheses are carried out at room temperature and under aqueous conditions, energy input is reduced and the solvents or agents used are nontoxic - factors that minimize environmental damage and enhance human health. The structural diversity of biomolecules results in nanoparticles with a wide range of sizes, shapes, and polymorphisms that determine their physical-chemical properties. As is well known, biomolecules can carry on slow kinetics to self-reduce metal precursors and develop stable coating layers to avoid particle aggregation. In particular, proteins with different functional groups as capping shells will facilitate postsurface modification for further biomedical applications.

Egg white or albumen is the liquid that surrounds the yolk of an egg. There are approximately 40 types of protein present in a chicken's egg white, all of which are beneficial to the human body. Besides their high nutritional quality, egg white proteins (ovalbumin) also have various functional properties such as gelling, foaming, emulsification, heat setting, and binding adhesion. ${ }^{22}$ Another advantage is their solubility in water and tendency to associate with metal ions in solution. Metal ions such as $\mathrm{Mn}^{2+} / \mathrm{Mn}^{3+}, \mathrm{Fe}^{2+} / \mathrm{Fe}^{3+}, \mathrm{Cu}^{2+}$, $\mathrm{Zn}^{2+}$, and $\mathrm{Ni}^{2+}$ have been combined with egg white to obtain novel nanomaterials with interesting properties. ${ }^{23-28}$

However, to date, it appears that the use of egg white as a template for the synthesis of noble metal nanoparticles has not been investigated, let alone these nanoparticles' application in cancer therapy. In the current paper, we report a simple, nontoxic, and eco-friendly green pathway to prepare stable spherical and spheroidal Ag-protein bio-conjugates by using egg white as a stabilizer and reductant.

\section{Materials and Methods Materials}

Fresh eggs were bought from a local supermarket. Silver nitrate $\left(\mathrm{AgNO}_{3}\right.$, analytical grade) was purchased from Sinopharm Chemical Reagent Co, Ltd (Shanghai, People's Republic of China). Purified water (18.2 $\mathrm{m} \Omega$-cm) was made using a Purelab Classic DI MK2 system (Veolia Water, Paris, France). Mouse fibroblast 3T3 cell line was kindly provided by Dr Jianbing Liu (School of Medicine, Shanghai Jiaotong University, People's Republic of China). Human breast adenocarcinoma cell line was kindly donated by Dr Jianming Luo (Fudan University Shanghai Cancer Center, People's Republic of China).

\section{Synthesis of Ag nanoparticles in the presence of egg white}

In a typical procedure, $1.0 \mathrm{~mL}$ egg white extract was fully dissolved in $97.0 \mathrm{~mL}$ water with a strong magnetic stirrer for
30 minutes. The cloudy white solution was filtered through two layers of gauze and a clear solution was obtained. Then, $2.0 \mathrm{~mL} 10.0 \mathrm{mM} \mathrm{AgNO}_{3}$ solution was added rapidly under vigorous stirring, bringing the total reaction volume to $100.0 \mathrm{~mL}$. The reaction was carried out at room temperature for 72 hours, and it was observed that the solution gradually changed from white to yellow within this time. The collected solution was centrifuged at $15,000 \mathrm{rpm}$ for 15 minutes then washed with purified water. This was repeated twice, and the final samples were dried under vacuum for further characterization.

\section{Characterization}

UV-vis spectra were measured using a Shimadzu UV-2450 UV-visible spectrophotometer (Shimadzu Scientific Instruments, Kyoto, Japan). Infrared spectra in the range of $400-4000 \mathrm{~cm}^{-1}$ were recorded using a Nicolet 870 Fouriertransform infrared (FTIR) spectrometer (Thermo Nicolet, Madison, WI). A small quantity of the sample was blended with dry potassium bromide for analysis. The size of the particles in the resulting mixtures was analyzed using a Beckman Coulter DELSA Nano C-Nano Particle Size Analyzer (Beckman Coulter Inc, Brea, CA). Transmission electron microscopy (TEM) measurements were performed at an accelerated voltage of $120 \mathrm{kV}$ (JEM-2010; JEOL Ltd, Tokyo, Japan).

\section{In vitro cytotoxicity assay}

Cell Counting Kit-8 (CCK-8; Dojindo Lab, Kumamoto, Japan) was employed in this experiment to evaluate the cytotoxicity of the Ag-protein bio-conjugates.

One hundred microliters of $3 \mathrm{~T} 3$ cell suspension was dispersed in a 96-well plate, giving a concentration of 5000 cells/well. The plate was pre-incubated for 24 hours in a humidified incubator $\left(37^{\circ} \mathrm{C}, 5 \% \mathrm{CO}_{2}\right)$, after which $10 \mu \mathrm{L}$ of various concentrations of $\mathrm{Ag}$-protein bio-conjugates were added into the culture media in the plate. After the plate was incubated for a further 24 hours, $10 \mu \mathrm{L}$ of CCK- 8 reagent was added to each well of the plate. The plate was then incubated for another 4 hours and then the plate's absorbance at $450 \mathrm{~nm}$ was measured using a microplate reader.

\section{X-ray irradiation enhancement test}

Ionizing radiation treatments were carried out using a standard radio-oncology linear accelerator (Siemens Oncor AvantGarde, Siemens Medical Solutions, Los Angeles, CA) with a $6 \mathrm{meV}$ beam irradiator at a dose rate of $1.0 \mathrm{~Gy} \mathrm{~min}^{-1}$. A sample of 231 cells was irradiated with different concentrations of 
Ag-protein bio-conjugates at room temperature, after which these cells were incubated for another 48 hours. Cell viability tests were determined by CCK- 8 . The same experiment was also performed with radio-resistant 231 cells.

\section{Results and discussion}

The general process for the synthesis of nanomaterials in egg white extract involves the electrostatic complexation of Ag ions with oppositely charged proteins, followed by the foam generation and subsequent in situ chemical reaction. ${ }^{18}$ Biomolecules with carboxyl, hydroxyl, and amine functional groups have the potential to reduce metal ion and cap the newly formed nanoparticles, ${ }^{29-31}$ which has allowed $\mathrm{Au}$ and $\mathrm{Ag}$ nanoplates to be obtained in green algal solutions. Similarly, various types of proteins with a large number of hydroxyl groups in egg white may be expected to attach to the different faces of Ag nanocrystals, leading to isotropic growth and the subsequent formation of stable spherical Ag nanoparticles.

Ag nanoparticles were first characterized using a UVvis spectrophotometer. As shown in Figure 1, the surface plasmon resonance peak occurred at $425 \mathrm{~nm}$, indicating the formation of spherical Ag nanoparticles (reddish-yellow color, inset). Additionally, the peak at $325 \mathrm{~nm}$ is ascribed to the protein characteristic.

FTIR has become an important tool in understanding the involvement of functional groups in interactions between metal particles and biomolecules. ${ }^{32}$ In the current study, FTIR measurements were performed to identify the biomolecules responsible for capping and stabilizing the Ag nanoparticles. As is shown in Figure 2, the spectra record was carried out in the range of $400-4000 \mathrm{~cm}^{-1}$. The very strong peak at $3442 \mathrm{~cm}^{-1}$ was assigned as $-\mathrm{OH}$ stretch of the proteins in the egg white extract. A peak was observed around $2950 \mathrm{~cm}^{-1}$

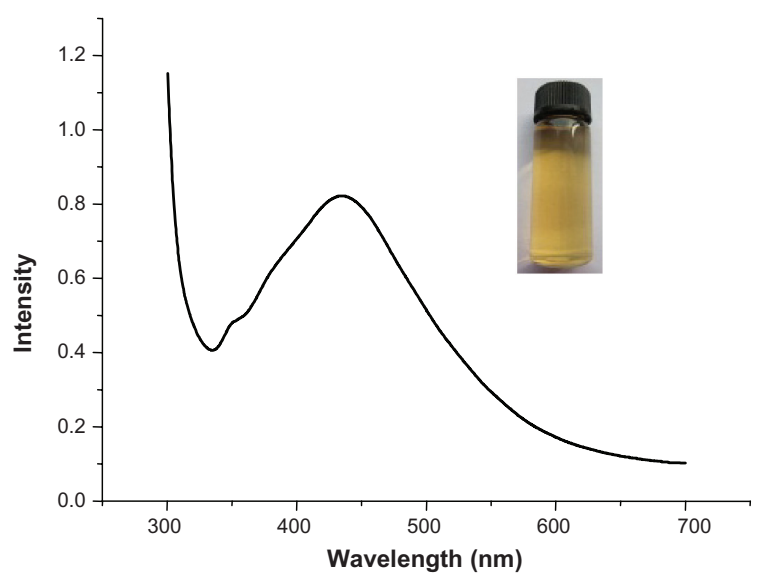

Figure I UV-vis spectrum of purified Ag egg-white nanoparticles. Note: Inset shows a typical optical image of the resulting product.

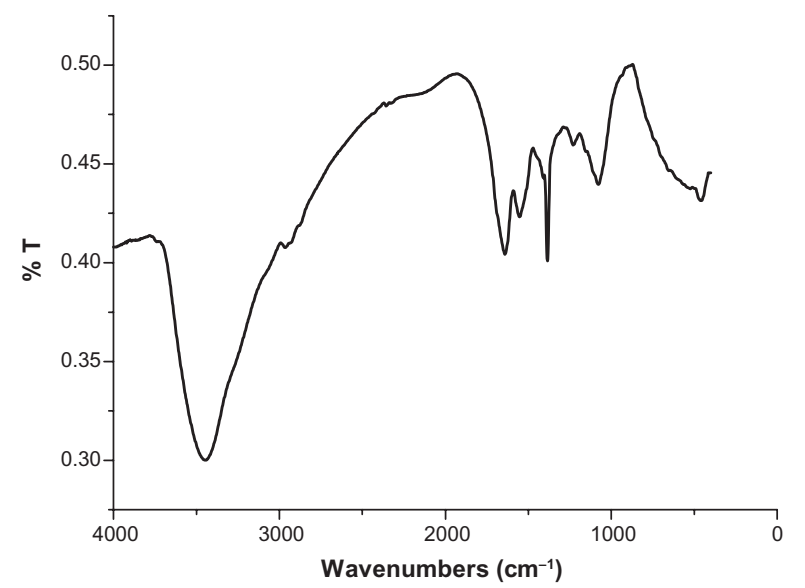

Figure 2 Fourier-transform infrared spectrum recorded from the powder of $\mathrm{Ag}$ nanoparticles synthesized through the use of an egg-white template.

that could be assigned to the $\mathrm{C}-\mathrm{H}$ stretching vibrations of methyl, methylene, and methoxy groups. The peak located at $1643 \mathrm{~cm}^{-1}$ was assigned to the $\mathrm{C}=\mathrm{O}$ stretching in carboxyl or $\mathrm{C}=\mathrm{N}$ bending in the amide group. The absorption band at $1539 \mathrm{~cm}^{-1}$ was characteristic of amide II $(\mathrm{N}=\mathrm{H})$ bonds of proteins. The peak at $1072 \mathrm{~cm}^{-1}$ was assigned to the stretch of the $\mathrm{C}-\mathrm{O}$ bond.

TEM and dynamic light scattering (DLS) were used to evaluate the size, morphology, and hydrodynamic size of the Ag nanoparticles. As can be seen in Figure 3A, the nanoparticles are homogeneous and spherical with an average diameter of $12 \mathrm{~nm}$. It was observed that the edges of the particles were lighter than the centers (Figure 3B), showing that biomolecules (such as proteins in egg white) coated the surface of the $\mathrm{Ag}$ nanoparticles. This is consistent with the FTIR results.

Given the importance of the hydrodynamic volume of nanoparticles for their biomedical implications, a DLS experiment was performed to study the polydispersity of the Ag nanoparticles in aqueous solution. The particle size distribution was fitted by a Gaussian curve as shown in Figure 4. It was ascertained that the particles were $154.2 \mathrm{~nm}$ in diameter, larger than was indicated by TEM. This was attributed to the
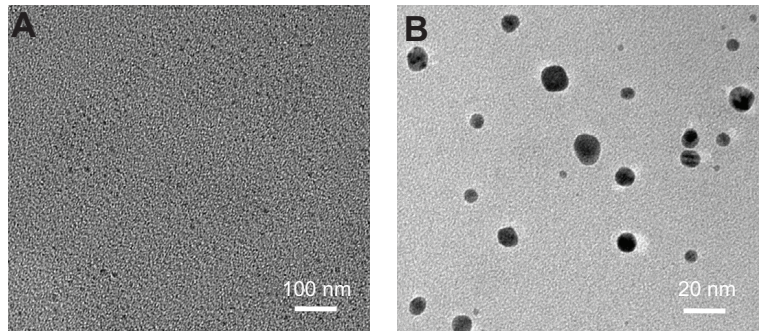

Figure 3 Transmission electron microscopy images of $\mathrm{Ag}$ nanoparticles at different magnifications, $(\mathbf{A})$ the lower image and $(\mathbf{B})$ the higher image. 


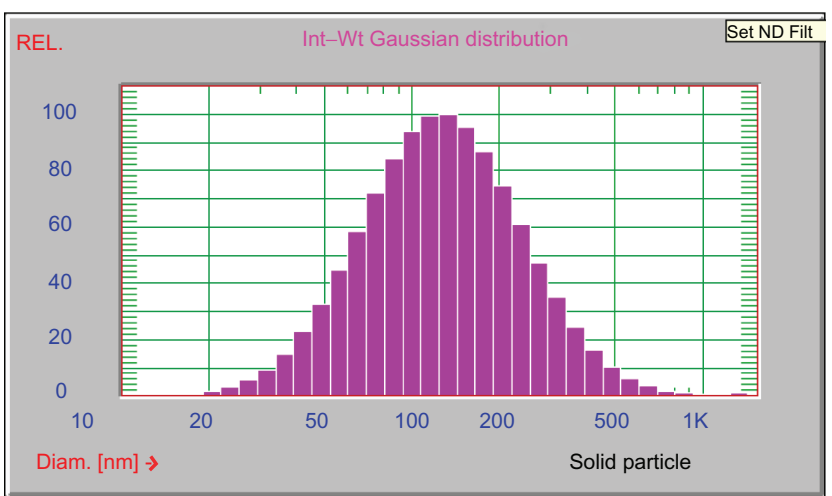

Intensity weighting:

Mean diameter $\quad=154.2 \mathrm{~nm}$

Stnd deviation $\quad=97.8 \mathrm{~nm}[63.40 \%]$

Cumulative result: Int-Wt Vol-Wt

$25 \%$ of deviation $<82.3 \mathrm{~nm}<32.5 \mathrm{~nm}$

$50 \%$ of deviation $<126.2 \mathrm{~nm}<47.7 \mathrm{~nm}$

$75 \%$ of deviation $<193.4 \mathrm{~nm}<71.6 \mathrm{~nm}$

Figure 4 Size distribution of the egg white and $\mathrm{Ag}$ ensemble in aqueous solution according to dynamic light scattering measurements.

fact that the DLS is sensitive to the size of the entire proteinnanoparticle ensemble as well as the water associated with this, while only the metallic crystal lattice is visible under the electron beam in bright-field TEM observations. ${ }^{33}$ Both the TEM and DLS exhibited a narrow particle size distribution, a finding which has important biomedical implications.

Potential biomedical applications of nanoparticles also depend greatly on their biocompatibility. Therefore, the cytotoxicity of Ag-protein bio-conjugates was examined under in vitro conditions in the mouse fibroblast cell line 3T3. This was assessed in terms of the effect of Ag-protein bio-conjugates on cell viability, determined by CCK-8 assay. After treatment with Ag-protein bio-conjugates for 24 hours, it was demonstrated that viability remains above $80 \%$ when the Ag-protein bio-conjugate concentration remained below $12 \mu \mathrm{g} / \mathrm{mL}$ (Figure 5). It has been reported that some Ag nanoparticles produce significant toxicity in cell culture media, ${ }^{34}$ while protein-coated Ag nanoparticles show minimal or no toxicity in a $3 \mathrm{~T} 3$ cell culture, which is consistent with the results of cinnamon phytochemical-coated Au nanoparticles. ${ }^{35}$ A possible explanation is that both of these are naturally occurring biomolecules that have evolved and have been proven safe in the human body. ${ }^{36,37}$ They supply a nontoxic coating for Ag nanoparticles, which provides biocompatibility for in vivo administrations. The lack of any noticeable toxicity of Ag-protein bio-conjugates thus presents new opportunities for safe delivery and applications of such nanopharmacuticals in molecular therapy.

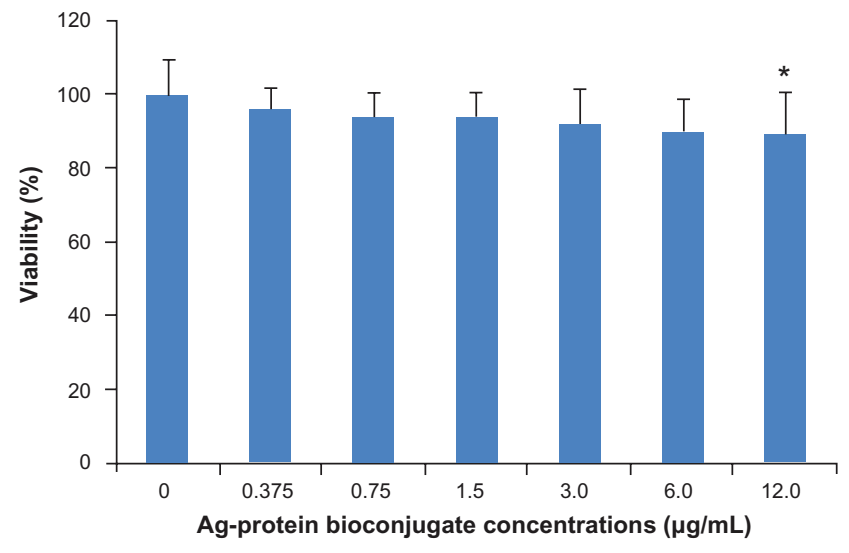

Figure 5 Cell viability of mouse fibroblast 3T3 cells after 24 hours' incubation with increasing amounts of Ag-protein bio-conjugates showing nontoxic profiles. Notes: Means \pm standard deviation; $\mathrm{n}=5 ; * P<0.05$.

To further explore their potential for biomedical application, an experiment was performed to assess the effects of Ag-protein bio-conjugates on 231 tumor cells when these were treated with X-ray irradiation. Radiotherapy is widely used in the clinical treatment of cancer and it is hoped that the rapid development of nanomedicine will allow nanomaterials to be combined with radiation therapy to produce a novel and effective strategy for the treatment of this disease. ${ }^{38}$ Besides preserving the advantages of standard radiotherapy, such as high penetration, the presence of nanoparticles can enhance radiotherapy's cancerkilling effect. However, this is dependent on nanoparticles becoming concentrated in cancerous regions and interacting strongly with the irradiating beam.

Although the detailed mechanism remains largely unexplored, it is clear that the presence of strongly absorbing elements in the cells can increase the production of photoelectrons or free radicals and lead to the damage of organelles and/or nuclei. It has been noted that Au nanoparticles can enhance the efficacy of radiation therapy on a murine squamous cell carcinoma, ${ }^{39}$ while glucose-capped $\mathrm{Au}$ nanoparticles can enhance radiation sensitivity in radiation-resistant human prostate cancer cells through regulation of the cell cycle. ${ }^{40}$ Other researchers have found that polyethylene glycol-modified Au nanoparticles accumulate at tumor sites and enhance the response of CT26 cells to X-ray irradiation ${ }^{1}$ and that fetal bovine serum-modified Ag nanoparticles increased the sensitivity of glioma cells to ionizing radiation (IR) treatment. ${ }^{41}$

The current study employed Ag-protein bio-conjugates as novel radiosensitizers. The Ag-protein bio-conjugates were applied to human breast adenocarcinoma 231 cells at different concentrations $(0 \mu \mathrm{g} / \mathrm{mL}, 0.375 \mu \mathrm{g} / \mathrm{mL}, 0.75 \mu \mathrm{g} / \mathrm{mL}$, $1.5 \mu \mathrm{g} / \mathrm{mL}, 3 \mu \mathrm{g} / \mathrm{mL}, 6 \mu \mathrm{g} / \mathrm{mL}$, and $12 \mu \mathrm{g} / \mathrm{mL}$ ) and $4 \mathrm{~Gy}$ $\mathrm{X}$-ray irradiation was applied. Figure $6 \mathrm{~A}-\mathrm{H}$ shows the 


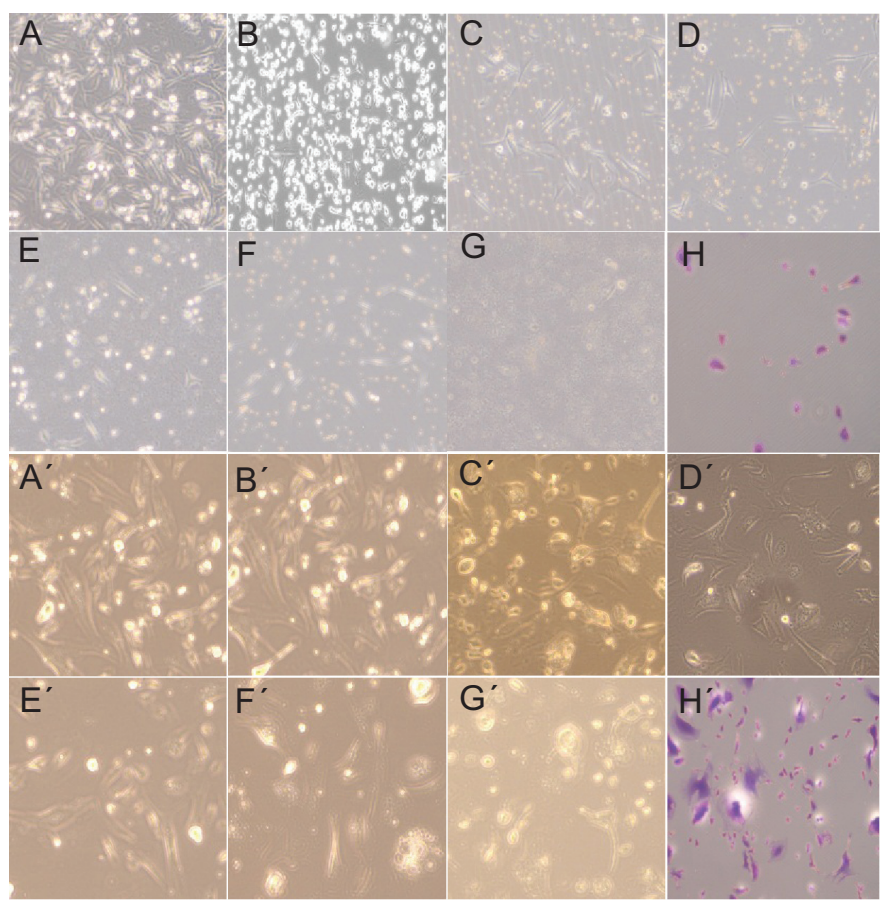

Figure 6 Optical pictures of $23 \mathrm{I}$ colonies. A-H are images of 4 Gy X-ray-irradiated 231 cells with the addition of Ag-protein bio-conjugate concentrations at $0,0.375$, $0.75, I .5,3.0,6.0$, and $12.0 \mu \mathrm{g} / \mathrm{mL}$ respectively. $\mathbf{A}^{\prime}-\mathbf{H}^{\prime}$ are images of $10 \mathrm{~Gy}$ X-ray-irradiated $23 \mathrm{I}$ cells (note that these cells were $4 \mathrm{~Gy} X$-ray resistant) with the addition of Ag-protein bio-conjugate concentrations at $0,0.375,0.75,1.5,3.0,6.0$, and $12.0 \mu \mathrm{g} / \mathrm{mL}$ respectively.

Note: $\mathbf{H}$ and $\mathbf{H}^{\prime}$ are the crystal violet-stained results corresponding $\mathbf{G}$ and $\mathbf{G}^{\prime}$, respectively.

number of changes and morphology of these changes to cancer cells following 24 hours' incubation. It is clear that the cell numbers decrease as nanoparticle concentration increases, and morphological changes are also observed with the addition of Ag-protein bio-conjugates. The spindles of treated cells become spherical in the presence of $\mathrm{Ag}$ nanoparticles and $\mathrm{X}$-ray (Figure 6B-H, in contrast to the control, Figure 6A). It was concluded that the combined use of nanoparticles and $\mathrm{X}$-ray treatment caused significant damage to the cells' cycle.

Since some solid tumors are radio resistant, 4 Gy-resistant 231 cells were selected and the irradiation dose was increased to $10 \mathrm{~Gy}$ to determine whether Ag-protein bio-conjugates are also available to radio-resistant cells. As is shown in Figure $6 \mathrm{~A}^{\prime}-\mathrm{H}^{\prime}$, the cell nuclei are larger than the corresponding cells exposed to $4 \mathrm{~Gy}$. This change in the nucleus could retard its division and lead to death.

A detailed study of cell survival is shown in Figure 7. These results will be discussed based on normal 231 cells and X-ray irradiated 231 cells with different Ag-protein bioconjugates concentrations. In the case of cells that received no X-ray irradiation, the survival of normal cells and the irradiated group remain very similar as Ag-protein bio-conjugates increase, indicating that the Ag-protein bio-conjugates possess good biocompatibility within the experimental concentrations.
When cells are exposed to a certain dosage of X-ray irradiation, the survival of both the normal and the irradiated cell groups begin to decrease as the Ag-protein bio-conjugate concentration increases. It was noted that the survival of the normal cells decreased more quickly than those that were irradiated, indicating that X-ray treatment kills more normal 231 cells

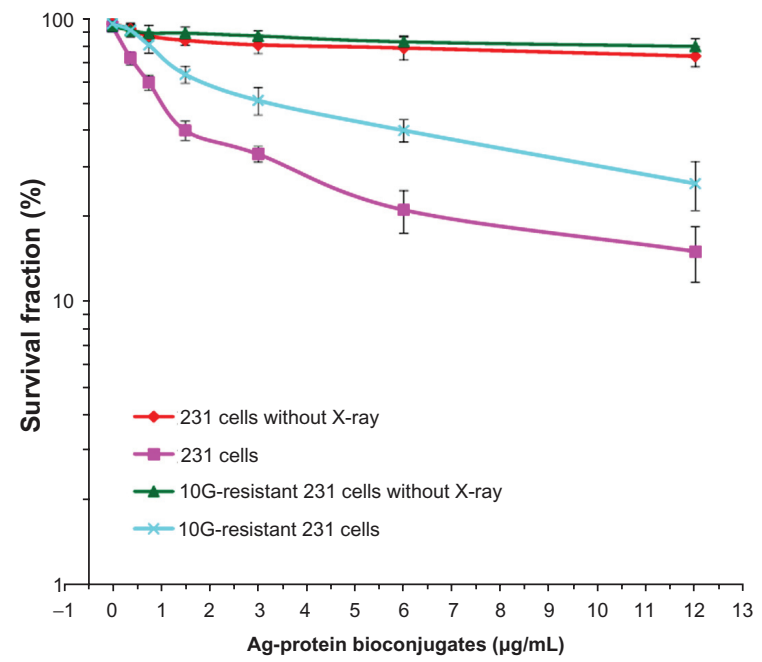

Figure 7 Survival curves of different strains of 23 I cells at different Ag-protein bioconjugate concentrations, contrasting those with/without $X$-ray irradiation. Clearly, the combined used of both Ag-protein bio-conjugates and $\mathrm{X}$-ray did enhance the irradiation to cancer cells.

Notes: Means \pm standard deviation; $\mathrm{n}=3$. 
when these have been treated with Ag-protein bio-conjugates. Both the irradiation dosage and Ag-proteins bio-conjugate concentration affected cell survival. These results suggest that Ag-protein bio-conjugates may function as a radio-therapeutic sensitizer in anticancer therapy. ${ }^{42}$

The practical clinical application of treatments such as this will ultimately depend on in vivo biological absorption, distribution, and metabolism of Ag-protein bio-conjugates. The researchers behind the current study will report on the mechanism behind the interactions between Ag-protein bioconjugates and cancer cells in the near future. This work will include detail across molecular, organ, and animal levels.

\section{Conclusion}

The current study has illustrated that egg white may be used as an active template for the spontaneous reduction of Ag ions and the consequent "one-pot" formation of protein-conjugated Ag nanoparticles. This synthesis method is very simple, costeffective, and environmentally friendly, and the nanoparticles produced were shown to be biocompatible through in vitro cell arrays. Further work is needed to investigate the mechanism of metal-ion uptake and bioreduction by egg white. This study also showed that Ag-protein bio-conjugates can strongly enhance the cell damage induced by X-ray irradiation, which suggests that protein-conjugated Ag nanoparticles are a promising candidate for the development of green nanomaterials for biomedical and health applications. ${ }^{43}$

\section{Acknowledgments}

The work was supported by Shanghai Science and Technology Commission (074119642), and the Shanghai Health Bureau Foundation (JGQN 08001).

\section{Disclosure}

The authors declare no conflicts of interest in this work.

\section{References}

1. Liu CJ, Wang CH, Chien CC, et al. Enhanced X-ray irradiationinduced cancer cell damage by gold nanoparticles treated by a new synthesis method of polyethylene glycol modification. Nanotechnology. 2008;19(29):295104.

2. West JL, Halas NJ. Engineered nanomaterials for biophotonics applications: improving sensing, imaging, and therapeutics. Annu Rev Biomed Eng. 2003;5:285-292.

3. Medintz IL, Uyeda HT, Goldman ER, Mattoussi H. Quantum dot bioconjugates for imaging, labelling and sensing. Nat Mater. 2005;4(6): 435-446.

4. Jain PK, Huang XH, El-Sayed IH, El-Sayed MA. Noble metals on the nanoscale: optical and photothermal properties and some applications in imaging, sensing, biology, and medicine. Acc Chem Res. 2008;41(12): 1578-1586.

5. Yang DP, Cui DX. Advances and prospects of gold nanorods. Chem Asian J. 2008;3(12):2010-2022.
6. Fan TX, Chow SK, Zhang D. Biomorphic mineralization: from biology to materials. Prog Mater Sci. 2009;54(5):542-659.

7. Dickerson MB, Sandhage KH, Naik RR. Protein- and peptide-directed syntheses of inorganic materials. Chem Rev. 2008;108(11):4935-4978.

8. Nadagouda MN, Varma RS. Green synthesis of silver and palladium nanoparticles at room temperature using coffee and tea extract. Green Chem. 2008;10:859-862.

9. Chanda N, Nune SK, Shukla R, et al. Green nanotechnology from tea: phytochemicals in tea as building blocks for production of biocompatible gold nanoparticles. J Mater Chem. 2009;19(19):2912-2920.

10. Chandran SP, Chaudhary M, Pasricha R, Ahmad A, Sastry M. Synthesis of gold nanotriangles and silver nanoparticles using Aloe vera plant extract. Biotechnol Prog. 2006;22(2):577-583.

11. Sharma J, Tai Y, Imae T. Biomodulation approach for gold nanoparticles: synthesis of anisotropic to luminescent particles. Chem Asian J. 2010;5(1):70-73.

12. Li S, Shen Y, Xie A, et al. Green synthesis of silver nanoparticles using Capsicum annuum L. extract. Green Chem. 2007;9:852-858.

13. Nadagouda MN, Varma RS. Green and controlled synthesis of gold and platinum nanomaterials using vitamin B-2: density-assisted self-assembly of nanospheres, wires and rods. Green Chem. 2006;8:516-518.

14. Yang DP, Chen SH, Huang P, et al. Bacteria-template synthesized silver microspheres with hollow and porous structures as excellent SERS substrate. Green Chem. 2010;12:2038-2042.

15. Zhang L, Shen YH, Xie AJ, Li S, Jin B, Zhang Q. One-step synthesis of monodisperse silver nanoparticles beneath vitamin E Langmuir monolayers. J Phys Chem B. 2006;110(13):6615-6620.

16. Keyes JD, Hilton RJ, Farrer J, Watt RK. Ferritin as a photocatalyst and scaffold for gold nanoparticle synthesis. J Nanopart Res. 2011;13(6): 2563-2575.

17. Xie JP, Zheng YG, Ying JY. Protein-directed synthesis of highly fluorescent gold nanoclusters. J Amer Chem Soc. 2009;131(3):888-889.

18. Singh AV, Bandgar BM, Kasture M, Prasad BL, Sastry M. Synthesis of gold, silver and their alloy nanoparticles using bovine serum albumin as foaming and stabilizing agent. J Mater Chem. 2005;15: 5115-5121.

19. Eby DM, Schaeublin NM, Farrington KE, Hussain SM, Johnson GR. Lysozyme catalyzes the formation of antimicrobial silver nanoparticles. ACS Nano. 2009;3(4):984-994.

20. Si S, Mandal TK. Tryptophan-based peptides to synthesize gold and silver nanoparticles: a mechanistic and kinetic study. Chem Eur J. 2007;13(11):3160-3168.

21. Huang P, Bao L, Yang DP, et al. Protein-directed solution-phase green synthesis of BSA-conjugated $\mathrm{M}(\mathrm{x}) \mathrm{Se}(\mathrm{y})(\mathrm{M}=\mathrm{Ag}, \mathrm{Cd}, \mathrm{Pb}, \mathrm{Cu})$ nanomaterials. Chem Asian J. 2011;6(5):1156-1162.

22. Mine Y. Recent advances in egg protein functionality in the food system. Worlds Poult Sci J. 2002;58:31-39.

23. Gabal MA. Structural and magnetic properties of nano-sized $\mathrm{Cu}-\mathrm{Cr}$ ferrites prepared through a simple method using egg white. Mater Lett. 2010;64(17):1887-1890.

24. Senthil SM, Jayaprakash R, Singh VN, Mehta BR, Govindaraj G. Synthesis and magnetic properties of nanosized cobalt substituted nickel ferrites $\left(\mathrm{Ni}_{1-}^{-} \mathrm{Co}_{x} \mathrm{Fe}_{2} \mathrm{O}_{4}\right)$ using egg white (ovalbumin) by thermal evaporation. Nano Res. 2008;4:107-116.

25. Senthil SM, Jayaprakash R, Murthy SR, Phani AR, Singh VN, Govindaraj G. Effect of annealing on dielectric property in $\mathrm{Ni}_{1^{-}}$$\mathrm{Co}_{x} \mathrm{Fe}_{2} \mathrm{O}_{4}$ nanoparticles synthesized using albumen (egg white). Nano Res. 2009;6:205-213.

26. Durmus Z, Baykal A, Kavas H, Direkçi M, Toprak MS. Ovalbumin mediated synthesis of $\mathrm{Mn}_{3} \mathrm{O}_{4}$. Polyhedron. 2009;28(11):2119-2122.

27. Nouroozi F, Farzaneh F. Synthesis and characterization of brush-like $\mathrm{ZnO}$ nanorods using albumen as biotemplate. $J$ Braz Chem Soc. 2011;22(3):484-488.

28. Maensiri S, Masingboon C, Laokul P, et al. Egg white synthesis and photoluminescence of platelike clusters of $\mathrm{CeO}_{2}$ nanoparticles. Cryst Growth Des. 2007;7(5):950-955. 
29. Xie JP, Lee JY, Wang DIC. Synthesis of single-crystalline gold nanoplates in aqueous solutions through biomineralization by serum albumin protein. J Phys Chem C. 2007;111(28):10226-10232.

30. Xie JP, Lee JY, Wang DIC, Ting YP. Silver nanoplates: from biological to biomimetic synthesis. ACS Nano. 2007;1(5):429-439.

31. Xie JP, Lee JY, Wang DIC, Ting YP. Identification of active biomolecules in the high-yield synthesis of single-crystalline gold nanoplates in algal solutions. Small. 2007;3(4):672-682.

32. Prathna TC, Chandrasekaran N, Raichur AM, Mukherjee A. Biomimetic synthesis of silver nanoparticles by Citrus limon (lemon) aqueous extract and theoretical prediction of particle size. Colloid Surf B Biointerfaces. 2011;82(1):152-159

33. Guerra J, Burt JL, Ferrer DA, Mejía S, José-Yacaman M. Influence of morphology in the catalytic activity of bioconjugated platinum nanostructures. J Nanopart Res. 2011;13(4):1723-1735.

34. Hussain SM, Hess KL, Gearhart JM, Geiss KT, Schlager JJ. In vitro toxicity of nanoparticles in BRL 3A rat liver cells. Toxicol In Vitro. 2005;19(7):975-983.

35. Chanda N, Shukla R, Zambre A, et al. An effective strategy for the synthesis of biocompatible gold nanoparticles using cinnamon phytochemicals for phantom CT imaging and photoacoustic detection of cancerous cells. Pharm Res. 2011;28(2):279-291.
36. Zhang HY, Yang DP, Tang GY. Multipotent antioxidants: from screening to design. Drug Discov Today. 2006;11(15-16):749-754.

37. Yang DP, Ji HF, Tang GY, Ren W, Zhang HY. How many drugs are catecholics. Molecules. 2007;12(4):878-884.

38. Chen W, Zhang J. Using nanoparticles to enable simultaneous radiation and photodynamic therapies for cancer treatment. $J$ Nanosci Nanotechnol. 2006;6(4):1159-1166.

39. Hainfeld JF, Dilmanian FA, Zhong Z, Slatkin DN, Kalef-Ezra JA, Smilowitz HM. Gold nanoparticles enhance the radiation therapy of a murine squamous cell carcinoma. Phys Med Bio. 2010;55(11): 3045-3059.

40. Roa W, Zhang XJ, Guo LH, et al. Gold nanoparticle sensitize radiotherapy of prostate cancer cells by regulation of the cell cycle. Nanotechnology. 2009;20(37):375101.

41. Xu R, Ma J, Sun XC, et al. Ag nanoparticles sensitize IR-induced killing of cancer cells. Cell Res. 2009;19(8):1031-1034.

42. Huang P, Yang DP, Zhang CL, et al. Protein-directed one-pot synthesis of Ag microspheres with good biocompatibility and enhancement of radiation effects on gastric cancer cells. Nanoscale. 2011;3(9):3623-3626.

43. Iravani S. Green synthesis of metal nanoparticles using plants. Green Chem. 2011;13:2638-2650.
International Journal of Nanomedicine

\section{Publish your work in this journal}

The International Journal of Nanomedicine is an international, peerreviewed journal focusing on the application of nanotechnology in diagnostics, therapeutics, and drug delivery systems throughou the biomedical field. This journal is indexed on PubMed Central,

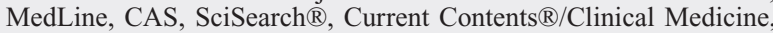

\section{Dovepress}

Journal Citation Reports/Science Edition, EMBase, Scopus and the Elsevier Bibliographic databases. The manuscript management system is completely online and includes a very quick and fair peer-review system, which is all easy to use. Visit http://www.dovepress.com/ testimonials.php to read real quotes from published authors. 